\title{
COMBATING BLACK MONEY: MONEY LAUNDERING AND TERRORISM FINANCE, INTERNATIONAL COOPERATION AND THE G8 ROLE
}

\section{Introduction}

In the aftermath of September 11th, growing attention has been paid to the role of Non-Cooperative Countries and Territories (NCCT) in money laundering and terrorist financing ${ }^{1}$. Policymakers concentrate their attention on the possibility that NCCT jurisdictions might facilitate the task of terrorists as well as criminal organizations (black money). Since 1989 the G7/G8 countries expressed the general commitment to define a strategy to combat black money (Table 1); on October 2001 the G7 Finance Ministers explicitly stressed the urgency to develop a process to identify jurisdictions that facilitate black money and to make recommendations for actions to achieve cooperation from such countries.

Two interacting principles commonly feature in the debate on the relationship between money laundering and NCCTs: a) money laundering is facilitated by lax financial regulation ${ }^{2}$; b) countries adopting lax financial regulation do not cooperate in the international effort aimed at combating money laundering ${ }^{3}$. These two principles characterized the mandate of the Financial Action Task Force $(\text { FATF })^{4}$ for the prevention of money laundering. On the one hand, to address the

\footnotetext{
${ }^{1}$ As Norgren (2004) noted, money laundering is defined as the processing of criminal proceeds to disguise their illegal origin in order to legitimize the gains of crime, while terrorist finance can be characterised as the direct or indirect provision of funds-illegal or legal—with the intention that they should used in terrorist acts. But the techniques are quite similar, or at least overlapping. On similarities and differences between money laundering and terrorism finance (or money dirtying) see Annex I and von Furstenberg 2004; see also Rider (2003), Masciandaro (2004). On the key role of the US legislation in promoting the international financial war against terrorism see Wasserman (2002), Banoun, Cephas and Fruchtman (2002), Preston (2003), Van Cleef (2003); see also Davis (2003).

2 On the relationship between money laundering and lax financial regulation see Annex II.

${ }^{3}$ See International Monetary Fund (1998), Holder (2003).

${ }^{4}$ The Financial Action Task Force on Money Laundering (FATF) is an inter-governmental organization that seeks to develop and promote policies at both national and international
} 
problems associated with money laundering risks it is fundamental to develop legal standards for rules and regulations. The FAFT standards (Recommendations) became the benchmark for measuring the degree of laxity of financial regulation in every country setting. On the other hand, to monitor the compliance of countries with international standards, the FAFT used a list of specific criteria-consistent with the standards - to determine the NCCT jurisdictions ${ }^{5}$.

The FAFT produces periodic reports on the NCCTs, commonly described as blacklists. From June 2000 to February 2004, nine NCCT lists have been published; the FATF has monitored a total of 45 countries, selected for their potential regulation weakness. Using a worldwide data set on the main 130 countries, we can highlight that these 45 countries represent $8 \%$ of total GDP, $15 \%$ of total population population, and $25 \%$ of foreign bank deposits in the world. Obviously these figures understate the overall relevance of the problem, given the relationships between the non-cooperative attitude, on the one hand, and the global economic and social costs due to the growth of the money laundering risks, on the other ${ }^{6}$.

Therefore the blacklist instrument represents the cornerstone of the international effort to reduce the risks that single countries or territories became havens for money laundering activities. But is this institutional device effective?

It has been argued ${ }^{7}$ that the overall result of the blacklisting mechanism is positive, since transparency regarding which countries do not comply has important effects in the financial markets, increasing the market pressures on the NCCT countries. But why is it, then, that various jurisdictions, notwithstanding the blacklist threat, delay or fail to change their rules, confirming their non-cooperative attitude (reluctant friend effect)? Furthermore, it is true that most jurisdictions placed on the black list have enacted regulatory measures in an effort to be

levels to combat money laundering. The FATF was established following the G7 Summit held in Paris in 1989. G7 members are: Canada, France, Germany, Italy, Japan, the United Kingdom (UK) and the United States (US). Initially, the FATF was convened from the G7 member States, The European Commission (EC) and eight other countries, but it now has a membership of 29 jurisdictions, with the EC and the Gulf Cooperation Council as international member organizations. The 29 member jurisdictions are: Argentina, Australia, Austria, Belgium, Brazil, Canada, Denmark, Finland, France, Germany, Greece, Hong Kong, Iceland, Ireland, Italy, Japan, Luxembourg, Mexico, Netherlands, New Zealand, Norway, Portugal, Singapore, Spain, Sweden, Switzerland, Turkey, the United Kingdom (UK) and the United States (US). The FATF has a small Secretariat that is housed in the headquarters of the OECD in Paris, but the FATF is a separate international body and not part of the OECD. See also Alexander (2001).

5 On differences and similarities between NCCT jurisdictions and offshore centres see Mitchell (2003), Alworth and Masciandaro (2004); on the offshore centres issues see also Errico and Musalem (1999), Hampton and Christensen (2002), Masciandaro (2004).

${ }^{6}$ On the qualitative and quantitative aspects of money laundering see Tanzi (2000).

${ }^{7}$ Norgren (2004). An economic analysis on the FAFT effects is performed by Johnson and Lim (2002). On the first different country reactions to the blacklisting process see Johnson (2001a) and (2001b) 
removed from it. But is regulatory reform sufficient to prove that a country has really changed its non-cooperative attitude (false friend effect)?

Perhaps the key problem is that discussions on these often take as agiven that some countries offer financial services to terrorism and organized crime by adopting lax financial regulations. In other words, lax financial regulation is treated as an independent variable. Therefore, any regulatory reform consistent with the international standards is sufficient to prove that the country is attempting to become a cooperative jurisdiction, while it fails to explain why specific countries continue in their non-cooperative attitude, notwithstanding the blacklist stigma.

This paper takes a different perspective. We develop the assumption that lax financial regulation may be a strategic dependent variable for national policymakers seeking to maximize the net benefits produced by any public policy choice. Therefore, given the structural features and endowments of their own countries, policymakers may it find profitable to adopt financial regulations that attract capital of illicit origin (money laundering services) or destination (terrorism finance services), therefore choosing to be a NCCT jurisdiction.

From a methodological point of view, we follow the classic intuitions of the new political economy, basing our work on three hypotheses: 1) the definition of regulatory policy is not independent, as in the conventional economics, but endogenous; 2) policy is not determined by maximizing a social welfare function but by taking into account the political cost-benefit payoff ${ }^{8}$; and 3) policymaker maximization is constrained and influenced by the structural framework, economic as well as institutional. We are also indebted to a strand of literature, usually associated with the 'law and economics' movement, which we deem to be strictly, though indirectly, related to the subject matter of our research, i.e. the literature on the competition in regulation. More specifically, we take the approach developed by authors that have tackled the issue in the "transaction cost economics" tradition" and apply it in a novel area.

The paper proceeds as follows. The second section provides a simple model to describe, through the policymaker payoff maximization, the relationships between specific country features and endowments, on the one hand, and lax financial regulations, on the other hand. Given that in the real world relatively lax regulation means a non-cooperative attitude in the international fight against money laundering, in the third section we empirically the above theoretical relationship in the case of the NCCT jurisdictions. The policy consequences on the pros and cons of international blacklisting procedures are discussed in the conclusive fourth section.

\footnotetext{
${ }^{8}$ For the new political economy see Drazen, (2000) and Persson and Tabellini, (2000).

9 See Romano (1985), (1993) and (1999).
} 


\section{Table 1 G7/G8 Terrorism Financing and Money Laundering: Main Steps}

1978- Bonn Statementon Air Hijacking: Terrorism enters in G7 Agenda.

1981 - Ottawa Summit: Statement on Terrorism.

1984-The London Declaration on International Terrorism: It's recognized the international character of the terrorist threat.

1986-Tokyo Summit: international effort against terrorism and first network of expert.

1989-Paris Summit: G7 recognizes the need of a financial action task force to fight money laundering.

1989- FATF is created.

1990-Huston Summit: G7 countries declare to commit to a full implementation of all FATF's 40 Recommendations.

1995-Ottawa, Ministerial Declaration on Counter Terrorism: guidelines to fight terrorism, among them "depriving terrorist of funds".

1996-Paris, Ministerial Conference on Terrorism, Agreement on 25 Measures: among them some measures specifically defined to prevent terrorist fund raising (goals No.19,20 and 21)

1997- Counterterrorism Directory of Skills and Competencies is created.

1998-G8 Justice and Interior Ministers Virtual Meeting on Organized Crime and Terrorism Funding: It's underlined international cooperation against money laundering and terrorist funding. French proposal for a UN Convention on terrorist financing.

1999- Moscow Conference: G8 supports the negotiations on the draft international convention against financing of terrorism

2000- Okinawa Summit: Action against Abuse of the Global Financing System where a comprehensive strategy against money laundering, tax havens and offshore financial centre is defined. G7 declares, if necessary, prepared itself to implement counter-measures against 15 non-cooperative countries identified by FATF.

G7 welcomes the creation of FIUs

2001-Rome, Fighting the Abuse of the Global Financial System (second report) where G7 monitors the FATF's work.

2001- (AfterSeptember 11): G8, condemning the terrorist attacks in New York and Washington, declares the need of a comprehensive, international strategy against terrorism and highlights the main role of specific financial measures.

2001 - The FATF's mandate to combat terrorist financing is expanded. G8 will implement UN sanctions to block terrorist assets.

Special Recommendation to fight terrorism financing are issued by FATF and the Action Plan of FATF is defined.

2001 - G7 issues Action Plan to Combat the financing of Terrorism. It's highlighted the linkage between terrorism prevention and financial abuses prevention. G7 is implementing UNSCR 1333 and UNSCR 1373. All States are called on to freeze terrorist funds and financial assets.

2001-IMF issues Communiqué of the International Monetary and Financial Committee where some specific measures against terrorist financing are set out.

2002-Ottawa: Progress Report on Combating the Financing of Terrorism: It's monitored the implementation of the strategy against terrorist financing.

2002-Many countries have set up a FIU.

2002 - Foreign Ministers' Progress on the Fight against Terrorism

2002-G8 Recommendations on Counter-Terrorism: a revision of the 25 Measures, adopted in Paris, 1996. 

2002-G7 Combating the Financing of Terrorism: First Year Report: It's monitored the implementation of the G7 Action Plan (2001).
2003-Evian Summit, Building International Political Will and Capacity to Combat Terrorism: a G8 Action Plan: It's underlined the need of an international cooperation and institutional network to support CTC, FATF and to encourage fulfilling UNSCR 1373 obligations. Creation of Counter- Terrorism Action Group (CTAG).
2004-Washington, Joint Statement on Combating Terrorist Financing

\section{Country Endowments, Policymakers and Lax Financial Regulation. A Simple Model}

To design the key elements of our approach, we shall use a very simple model, in order to present the economic intuitions in a compact and casual framework. Our goal is to discuss the possible relationships between specific country features, policymaker payoff maximization and lax financial regulation against money laundering, highlighting the key variables of the problem.

Let us assume that a policymaker is aware that a potential demand for money laundering exists on the part of one or more criminal or terrorist organizations ${ }^{10}$, for a total amount equal to $W$. We analyze a situation in which the international market for money laundering is demand-driven, as it is likely to be in the real world. Therefore every potential lax regulation jurisdiction is a relatively "small country".

The policymaker can decide to launder an amount of money equal to $Y$, where, of course, $0<Y<W$. For the sake of simplicity in our model, the decision on the optimal level of money laundering services is equivalent to the choice of the optimal degree laxity in financial regulation. Calling $U$ the payoff function of the policymaker, it is obvious that the expected payoff from unlaundered liquidity is zero, whatever the amount:

$$
U(W-Y)=0
$$

On the other hand every dollar (or euro?) ${ }^{11}$ laundered can have a positive expected value for the policymaker, if his country, given scarce natural resources, derives benefits from offering financial services that facilitate money laundering. In particular, we can intuitively assume that the lower the national income and the

\footnotetext{
${ }^{10}$ For a general microeconomic analysis of the money laundering demand see Masciandaro (1996) and (1998). For the peculiar relationship between money laundering demand and tax evasion see Yaniv (1994) and (1999); see also Alldridge (2001).

${ }^{11}$ For the use of dollar or euro in the black economy, see Boeschoten and Fase (1992), Rogoff (1997), Sinn and Westermann (2001).
} 
higher the proportion of that income that depends on the financial industry, the greater will be the propensity to offer money laundering services, all other things being equal. In general, let us to define those expected benefits as laxity national benefits.

To be more precise, the fact that the laundered money provides an expected profit for the policymaker may be captured by imagining that the monetary value $B$ of this benefit is equal to:

$$
B=m Y
$$

Where $m>0$ is the expected net rate of return on the money laundering services offered (i.e. on the degree of laxity) by the country. The inflow of black and grey foreign capital produces national revenues, increasing the activity of the financial industry and then throughout the traditional macroeconomic multiplier effects ${ }^{12}$. On the contrary, the implementation of a severe regulation against money laundering in the same country generates high compliance costs ${ }^{13}$. The role of the financial industry represents an economic endowments that determine the policymaker choices.

If the decision to launder were cost-free, it would be a trivial matter to see that we shall have $Y=W$. But things are not that simple.

First of all, policymakers may face international reputation costs. To be more attractive to criminal or terrorist organizations, a country must make legislative and regulatory choices that increase its credibility as a lax financial regulation (LFR) jurisdiction ${ }^{14}$. These choices may carry a reputation cost, however, since being an LFR jurisdiction may cause negative repercussions, whether in relation to capital, intermediaries and companies sensitive to integrity or to international relations in general. In fact, we have to acknowledge the possibility that under-regulation may be as unattractive for some legal investors as over-regulation ${ }^{15}$. As we noted in the Introduction, the existence of the international reputation costs represents the rationale for the blacklisting device.

Secondly, a policymaker must consider that laundering money means strengthening internal organized crime or terrorism, i.e. there may be national crime and terrorism costs. Policymakers have to consider the possibility that domestic social damage may derive from the fact that the country may became a

\footnotetext{
${ }^{12}$ For a macroeconomic analysis of the interrelationships between money laundering, banking industry, legal and illegal economic sectors see Masciandaro (2000). For the peculiar vulnerability of securities markets see Jayasuriya (2003).

${ }^{13}$ Masciandaro (1999).

${ }^{14}$ Masciandaro and Portolano (2003).

${ }^{15}$ The inflow of legal capital can be assumed as negatively correlated with financial laxity, because of two main effects: 1) in the legal financial sector, competition is distorted and the allocative efficiency of the market is undermined because of extreme financial laxity (competition effect); and 2) legal customers may fear a loss of reputation by locating their business in a country highly suspected for money laundering (reputation effect). See Basel Committee on Banking Supervision (1988).
} 
possible growth engine for illegal organizations. It is obvious, on the other hand, that the less the country registers the actual or potential presence of criminal or terrorist organizations internally, the lower the policymaker will perceive the costs of crime to be. The level of criminal and terrorism risk is a peculiar social endowment that influences the policymaker decisions.

Within our framework, we do not separate expected crime costs from expected terrorism costs. From the theoretical standpoint, we prefer to stress the different sensitivity of the policymaker to expected international costs and expected national costs, based on a clearly different political cost-benefits analysis. Furthermore, for each country, it should not be difficult to introduce in expression (3) a specific parameter for each expected national cost factor.

Therefore the overall cost $C$ of offering money laundering for a policymaker will consist of two parts. First, let us assume that the reputation cost is proportionalaccording to a parameter $c>0$ - to the amount of money he is asked to launder. Secondly, there will be a crime or terrorism cost whose expected value rises as the amount of laundered money increases, by a multiple of the parameter $\gamma>0$. Let us assume that for political-electoral reasons the policymaker, all other things being equal, is more sensitive to the crime and/or terrorism costs, which can weigh directly on the country's citizens, than to the international reputation costs, whose effect on the citizens-voters is probably less perceptible and direct. We have:

$$
C=c Y+\gamma^{2} Y
$$

Finally, we must consider that being a lax financial regulation jurisdiction could be an increasing source of economic, political and social risk for the international community as a whole. Therefore, when policymakers decide whether and to what extent to institute a financial regulatory design that will in essence offer money laundering services, they must consider that this activity is risky, since presumably the international community might consider it a bad policy, perhaps even prohibited, and as such subject to sanctions and punitive countermeasures.

Let us assume, therefore, that offering de facto money laundering services may bring with it an international sanction, with an equivalent monetary value of $S$, and a probability $p$ that this conduct will be discovered by the international community and thus sanctioned. The probability $p$ can be defined as the degree of technical enforcement of the international stigma. Let us call these risks the expected international sanction costs. Our model can thus contemplate in the simplest way the possibility that the international community will issue explicit sanctions against the LFR country ${ }^{16}$.

The monetary value of the damage from sanctions $S$ against the money laundering must at least equal the value $Y$ of the laundered money. In reality, the damage from a sanction is certainly a multiple, because of the value of the intangible non economic damage related to such an international sanction. So we can assume that

\footnotetext{
16 Sanctions and enforcements characterized the classic a' la Becker approach: Becker (1968).
} 
the amount of the international sanction is a multiple of the "laundry" volume, equal, for simplicity of computation, to the square of that sum.

And we should also consider that once the crime is recognized, the international community would apply the sanction with a varying degree of severity, based on its own political cost-benefit analysis. The rapidity and procedure for applying the punishment may vary, affected by national or international structural variables; this severity with which the sanction is applied (or the degree of international political enforcement $)^{17}$ can be captured by variations in the parameter $t$ :

$$
S=t Y^{2}
$$

Thus the dilemma of choice facing a policymaker is the following: if I design lax financial regulations that favor the offering of money laundering services, and the international community does not sanction it, the benefit for the country is positive, net of the expected cost associated with international reputation costs and national crime and terrorism risks. If, on the other hand, the LFR country is hit by an explicit international sanction, it will not only sustain the relative costs but will also be damaged by the international sanction. This game is the classic interaction between the policymaker and Nature, given that we assume the "small country" hypothesis.

The policymaker, modeled as a risk-neutral agent, is thus faced with the problem of deciding whether and how much to launder, i.e. defining the optimal level of laxity. The optimal policy is not derived by any social utility function but is just the result of the policymaker's maximizing process, based on his own political costbenefits analysis.

The policymaker's expected payoff $E$ can now be better specified as:

$$
E(U)=[(1-p)(B-C)-p(C+S)]
$$

But since we have defines $B=m Y$ and $C=c Y+\gamma^{2} Y$, then 5) becomes:

$$
E(U)=(1-p)\left\{m Y-c Y-\gamma^{2} Y\right\}-p\left(c Y+\gamma^{2} Y+t Y^{2}\right)
$$

Therefore It is possible to define the policymaker's optimal level of laxity, depending, coeteris paribus, on the structural parameters of the model, that represent specific country endowments.

$$
Y^{*}=\frac{m(1-p)-c-\gamma^{2}}{2 p t}
$$

\footnotetext{
${ }^{17}$ Rider (2002) noted that, in the field of financial regulation, international monetary policy has been susceptible to political considerations.
} 
$Y^{*}$ represents the optimal level of money laundering supply services, which is equivalent to the optimal degree of financial regulation laxity. Let us observe that for $\mathrm{Y}^{*}>0$ it must be $m(1-p)-c-\gamma^{2}>0$, i.e. the factor of expected benefit from the money-laundering activity, considering the probability of an international sanction, is greater than the sum of the reputation and crime and terrorism cost factors. Let us define this condition as the laxity condition.

Now we can evidence the relationships with the structural variables of the model for the optimal level of laxity. Firstly, the optimal offering of money laundering will be inversely proportional to the probability of international sanctions:

$$
\begin{aligned}
\frac{\partial Y^{*}}{\partial p}= & \frac{\left(c+\gamma^{2}-m\right)}{2 p^{2} t}<0 \\
& \quad \frac{\partial^{2} Y^{*}}{\partial p}=\frac{-4 p t\left(c+\gamma^{2}-m\right)}{4 p^{4} t^{2}}=\frac{m-c-\gamma^{2}}{p^{3} t}>0
\end{aligned}
$$

Secondly, the laxity of financial regulation is affected by the severity of the international community in applying the sanction:

$$
\frac{\partial Y^{*}}{\partial t}=\frac{-2 p\left[m(1-p)-c-\gamma^{2}\right]}{4 p^{2} t^{2}}<0
$$

The laxity of financial regulation will also depend on the profitability of offering money-laundering services:

$$
\frac{\partial Y^{*}}{\partial m}=\frac{(1-p)}{2 p t}>0
$$

Furthermore, we can express the relationship between the reputation cost of money-laundering operations and the amount of money to be laundered :

$$
\frac{\partial Y^{*}}{\partial c}=\frac{-1}{2 p t}<0
$$

Finally, the money-laundering activity of the LFR country will also depend on the expected crime and terrorism costs, represented by the parameter $\gamma$ : 


$$
\frac{\partial Y^{*}}{\partial \gamma}=\frac{-\gamma}{p t}<0
$$

\section{Lax Financial Regulation and Non Co-Operative Countries: An Empirical Investigation}

In the previous paragraph we illustrated the following relationship in a formal framework: given the specific structural features and endowments of his own country, a policymaker may find it rational to design lax financial regulations in order to attract capital of illegal origin.

The policymaker finds it advantageous to transform his country into an LFR jurisdiction because, in defining its objective function, the national economic benefits expected from offering money-laundering services are greater than the expected national costs associated with the internal risk of developing terrorism and organized crime, the international risk of loss of reputation and, finally, the possibility of a sanction by the international community. Therefore, peculiar economic and social country endowments can increase the probability of having lax financial regulation.

Now, how we can test this relationship? In the real world, the international community considers LFR countries as potential non-cooperative jurisdictions (NCCTs) in the fight against money laundering. Therefore we can assume that the NCCT jurisdictions share common structural features; we can test this hypothesis using econometric techniques.

In particular, since the international context (i.e. the technical and political enforcement described in our model) is constant, we can assume that:

- An NCCT jurisdiction will be one that, in terms of economic characteristics, has relatively scant physical resources to spend in international trade, and that this is the first channel of national benefit expected from lax financial regulation;

- At the same time, an NCCT jurisdiction has the potential for developing financial services, fundamental for money-laundering purposes, and this is the second channel of national benefit expected from lax financial regulation ;

- $\quad$ An NCCT jurisdiction also has social characteristics that shield it to some extent from the risks of terrorism and/or of organized crime, thus reducing the expected cost of lax financial regulation;

Now the time has come to analyze the NCCT jurisdictions. Since 22 June 2000, the FATF has been publishing a periodic report on the NCCT jurisdictions: the blacklist. The report lays down 25 criteria, plus eight recent special recommendations on terrorist financing, that, if violated, identify the national rules that in each country are detrimental to international cooperation in the fight against money laundering. From June 2000 to February 2004, 45 countries have been 
monitored, and nine blacklists have been published, indicating the jurisdictions that fail to conform to the criteria.

Having identified a sample of NCCT jurisdictions, it is possible to perform some econometric exercises. Using a worldwide data set on the main 130 countries $^{18}$, we do a Probit analysis. The dependent variable is a Binary Probit Variable equal to 1 for the 45 potential NCCTs and 0 otherwise.

The best estimated equation ${ }^{19}$ is as follows:

$$
(\text { BinaryLI })_{t}=\beta_{1}+\beta_{2}(A 1)_{t}+\beta_{3}(C 1)+\beta_{4}(E 1)+\varepsilon_{t}
$$

with $t=1 \mathrm{~K} N$

where:

$$
\begin{aligned}
& A 1=\text { Landuse }^{20} \\
& B 1=\text { GDP per capita } \\
& C 1=\text { Foreign deposits per Capita } \\
& E 1=\text { Terrorism and organized crime }
\end{aligned}
$$

${ }^{18}$ Given the 267 world countries (UN members=180), our 130 countries (BRI sample) represent the $98 \%$ of the world GDP and the $90 \%$ of the world population.

${ }^{19}$ Masciandaro and Portolano (2004).

${ }^{20}$ Landuse: This entry contains the percentage shares of total land area for five different types of land use: arable land - land cultivated for crops that are replanted after each harvest like wheat, maize, and rice; permanent crops - land cultivated for crops that are not replanted after each harvest like citrus, coffee, and rubber; permanent pastures - land permanently used for herbaceous forage crops; forests and woodland - land under dense or open stands of trees; other - any land type not specifically mentioned above, such as urban areas. Source: Central Intelligence Agency.

${ }^{21}$ Gdp-capita: This entry shows GDP on a purchasing power parity basis divided by population (year 2001). Source: Central Intelligence Agency

${ }^{22}$ Fordepositscapita: The data on foreign deposits are derived from reporting as such or calculated by subtracting separately reported data on positions other than deposits from total external assets and liabilities. The only exception is the Netherlands Antilles, which does not provide this information separately (year 2001). Source: BRI. The deposit data are then divided by the popolation (year 2001).

${ }^{23}$ Regarding the Organized Crime Dummy, the size of the drug market dimension is evidently an indirect and imperfect indicator of the organized crime problem. At the same time, the drug market has given organized crime its massive resources. It has been correctly noted that during the " 70 s the drug trade became far too profitable and easy for even traditional and "conservative" organized crime organisations to ignore (see Rider (2002), pag.17), Furthermore, it is also noted there that even terrorist groups entered the market and by so doing became virtually indistinguishable from "ordinary" organized crime.

${ }^{24}$ Terrorism and Organized Crime Index: we built this variable by summing two separate variables for each country: Organized Crime Dummy $=1$ if there is drug production and/or drug markets in the country, 0 otherwise (Source: CIA); Normalized Terrorism Indicator $=$ average number of terrorist episodes in the country (years 1968-91) $/ \max$ 
Table 2 Binary Laxity Index determinants (130 countries and territories)

\begin{tabular}{|lc|}
\hline Dependent variable & Binary Laxity Index \\
\hline Landuse & $0.0079108 * * * *$ \\
& $(0.003060)$ \\
Gdpcapita & $-0.0000723 * * * *$ \\
& $(0.0000190)$ \\
Fordepositcapita & $3.18 \mathrm{E}-06 * * * *$ \\
& $(1.36 \mathrm{E}-06)$ \\
Terrorismorgcrime & $-0.5737521 * * * *$ \\
& $(0.2436112)$ \\
\hline
\end{tabular}

STANDARD ERRORS IN PARENTHESES. SUPERSCRIPT ASTERISKS INDICATE STATISTICAL SIGNIFICANCE AT $0.01(* * * *), 0.02(* * *), 0.05(* *), 0.10(*)$.

The econometric results (Table 2) seem interesting, generally confirming that the probability of being an NCCT jurisdiction will depend on specific country endowments .

Firstly we note that the probability a country will become an NCCT jurisdiction tends to be higher the more it experiences economic growth problems, measuring those problems in terms of per-capita GDP and the level of land exploitation. This variable represents a proxy of the first channel of national laxity benefits .

Secondly we note that the probability a country will become an NCCT jurisdiction tends to be higher the more it has developed the flow of foreign deposits. This variable represents a proxy of the second channel of national laxity benefits.

Thirdly we use a joint Index of the terrorism risks and organized crime risks. In our approach, every national policymaker cares about both risks, and lax financial

average number of terrorist episodes in a country (1968-91); the Terrorism indicator therefore ranges from 0 to 1 (Source: Blomberg). Consequently, our Index ranges from 0 to 2

Data Sources; Central Intelligence Agency - www.cia.gov/cia/publications/factbook; Democracy Index - www.geocities.com/CapitolHill/Lobby/3535/country/list-di.htm; Foreign Bank Deposits: Bank for International Settlements www.bri.org/publ/qtrpdf/r_qa0206.pdf\#page $=44$; ; Terrorism Indicators, see Blomberg B.S., Hess D.G., Weerapana A., Terrorism From Within: An Economic Model of Terrorism, May 2002 and ITERATE Data Set. 
regulation can benefit in principle either terrorism or organized crime. In fact we note that the probability a country will become an NCCT jurisdiction tends to be higher as the degree of terrorism and organized crime risks decrease. We must point out that we have found no data for testing the role of international reputation sensitivity (Proposition Five) ${ }^{25}$.

It is possible to do a further step if we hypothesize different levels of noncooperative attitude. We can transform in an order probit variable Table 3) the fact that the 45 NCCTs jurisdictions have different stories: countries just monitored by the FAFT (non-cooperative attitude $=1$ ), countries with at least one presence in the black list (non-cooperative attitude $=2$ ), and finally the countries that actually remain in the black list (non-cooperative attitude $=3)^{26}$; the non-cooperative attitude is obviously 0 for the other 85 countries of the sample.

\footnotetext{
25 Obviously we cannot use a cross-country analysis to test the role of international economic and political enforcement, since from the standpoint of traditional economic policy the variables are not country-specific, while from the standpoint of new political economics, they should be more testable prima facie using country case studies.

${ }^{26}$ The following list of NCCTs is current and was last changed on February 2004: Cook Islands, Guatemala, Indonesia, Myanmar, Nauru, Nigeria, Philippines .
} 
Table 3 Ordered Laxity Index (OLI)

\begin{tabular}{|c|c|c|}
\hline & Countries & OLI \\
\hline 1 & Antigua & 1 \\
\hline 2 & Bahamas & 2 \\
\hline 3 & Barbuda & 1 \\
\hline 4 & Belize & 1 \\
\hline 5 & Bermuda & 1 \\
\hline 6 & British Virgin I. & 1 \\
\hline 7 & Cayman I. & 2 \\
\hline 8 & Cook I. & 3 \\
\hline 9 & Cyprus & 1 \\
\hline 10 & Czeck Republic & 1 \\
\hline 11 & Egypt & 2 \\
\hline 12 & Dominica & 1 \\
\hline 13 & Gilbratar & 1 \\
\hline 14 & Grenada & 2 \\
\hline 15 & Guatemala & 3 \\
\hline 16 & Guernsey & 1 \\
\hline 17 & Hungary & 2 \\
\hline 18 & Indonesia & 3 \\
\hline 19 & Isle of Man & 1 \\
\hline 20 & Israel & 2 \\
\hline 21 & Jersey & 1 \\
\hline 22 & Lebanon & 2 \\
\hline 23 & Liechtenstein & 2 \\
\hline 24 & Malta & 1 \\
\hline 25 & Marshall I. & 2 \\
\hline 26 & Mauritius & 1 \\
\hline 27 & Monaco & 1 \\
\hline 28 & Myanamar & 3 \\
\hline 29 & Nauru & 3 \\
\hline 30 & Nigeria & 3 \\
\hline 31 & Niue & 2 \\
\hline 32 & Panama & 2 \\
\hline 33 & Philippines & 3 \\
\hline 34 & Poland & 1 \\
\hline 35 & Russia & 2 \\
\hline 36 & Samoa & 1 \\
\hline 37 & Seychelles & 1 \\
\hline 38 & Slovak Rep. & 1 \\
\hline 39 & St. Kitts Nevis & 2 \\
\hline 40 & St. Lucia & 1 \\
\hline 41 & St. Vincent & 2 \\
\hline 42 & Turk Caicos & 1 \\
\hline 43 & Ukraine & 2 \\
\hline 44 & Uruguay & 1 \\
\hline
\end{tabular}




$45 \quad$ Vanuatu 1

We carry out an Ordered Probit analysis with the following results( Table3):

Table 3 Ordered Laxity Index determinants (130 countries and territories)

\begin{tabular}{|lcc|}
\hline Dependent variable & Ordered Laxity Index & \\
\hline Landuse & $0.0135717 * * * *$ & $0.0144398 * * * *$ \\
& $(0.0049385)$ & $(0.0049597)$ \\
Gdpcapita & $-0.0000523 * * *$ & $-0.0000527 * * * *$ \\
& $(0.0000155)$ & $(0.0000161)$ \\
Fordepositcapita & $8.86 \mathrm{E}-08 * * *$ & $9.04 \mathrm{E}-08 * * *$ \\
& $(3.98 \mathrm{E}-08)$ & $(4.05 \mathrm{E}-08)$ \\
Terrorismorgcrime & -0.3313072 & \\
& $(0.2245221)$ & $-0.4018445 *$ \\
Organized crime & & $(0.2414516)$ \\
Terrorism & & 0.0099674 \\
& & $(0.0293882)$ \\
& & \\
& & \\
& & \\
& & \\
& & \\
\end{tabular}

STANDARD ERRORS IN PARENTHESES. SUPERSCRIPT ASTERISKS INDICATE STATISTICAL SIGNIFICANCE AT $0.01(* * * *), 0.02(* * *), 0.05(* *), 0.10(*)$.

The regression confirms the robustness of the two channels of national laxity benefits, while the proxy of the terrorism and organized crime risks has the right sign, but it is not significant. If we split the organized crime dummy from the terrorism dummy, we find that the non-cooperative attitude is inversely related with the organized crime risk.

Finally, the econometric analysis allows us to affirm that the non-cooperative attitude does not coincide with the harmful tax competition attitude. While there is a theoretical presumption that international tax evasion and money laundering through offshore centres should overlap ${ }^{27}$, this is not necessarily the case.

We carried out another Probit analysis where the dependent variable is now an Offshore Binary Probit Variable, that is equal to 1 for the OECD offshore countries and 0 otherwise $^{28}$ (Table 4).

\footnotetext{
${ }^{27}$ Yaniv (1994) and (1999), Alworth and Masciandaro (2004).

${ }^{28}$ Alworth and Masciandaro (2004).
} 


\section{Table 4 Comparing Binary Offshore Index and Binary Laxity determinants (130 countries and territories)}

\begin{tabular}{l|ll}
\hline Dependent Variable & Binary Laxity Index & Binary Offshore Index \\
& & \\
\hline Landuse & $0.007 * * *$ & -0.002 \\
& $(0.003)$ & $(0.005)$ \\
Gdpcapita & $-7.07 \mathrm{E}-05 * * * *$ & $-2.04 \mathrm{E}-07$ \\
& $(1.92 \mathrm{E}-05)$ & $(2.60 \mathrm{E}-07)$ \\
Fordepostcapita & $3.18 \mathrm{E}-06 * * * *$ & $1.71 \mathrm{E}-06$ \\
& $(1.36 \mathrm{E}-06)$ & $(1.33 \mathrm{E}-08)$ \\
Terrorismorgcrime & $-0.508 * * *$ & $-1.888 * * * *$ \\
& $(0.224)$ & $(0.448)$ \\
\hline \multicolumn{2}{c}{ STANDARD ERRORS IN PARENTHESIS. SUPERSCRIPT ASTERISKS INDICATE STATISTICAL } \\
\multicolumn{2}{|c}{ SIGNIFICANCE AT $0.01(* * * *), 0.02(* * *), 0.05(* *), 0.10(*)}$.
\end{tabular}

As can be see, with the exception of the crime and terrorism index, none of variables have any explanatory power. This seems to suggest that the underlying economic characteristics of offshore centres and our NCCTs tend to differ. In general, therefore, we can reject the hypothesis that the causes of lax financial regulation decisions and of offshore activities are exactly the same.

In conclusion, the non-cooperative attitude seems to be dependent on key structural features of the country. Now, what are the consequences of our analysis on the debate concerning the effectiveness of blacklisting procedures?

\section{Conclusions. Is Blacklisting an Effective Device?}

In this paper we theoretically discuss and empirically test the relationships between specific country features, policymaker choices toward lax financial regulation, and national non-cooperative attitude with respect to the international effort to combat money-laundering phenomena. Our results suggest two main prescriptions for designing international policies aimed at reducing the global risks of terrorism and organized crime. These prescriptions can help to identify a possible role for the G8 countries in combating black money.

First of all, a pure and just formal "name and shame" approach may even prove counterproductive. Assuming that the international community is capable of effectively singling out NCCT jurisdictions that are indeed involved in black money schemes, a cautious approach is still deemed necessary. When the 
international community points the finger at a given country as a leading supplier of money-laundering financial services, it may also be certifying, to the benefit of the country itself, that that country is indeed specialized in that business. The signaling effect embedded in the "name and shame approach" should not be underestimated. The main difficulty for a genuine LFR country is credibly solving the commitment problem. Then, what is a better choice for an LFR country than having the international community-not exactly its closest friends-solving that problem through a public statement certifying a non-cooperative attitude (reluctant friend effect)?

Listing should also be regarded as a sort of third party bonding, which is likely to generate two interacting effects. First, it is capable of cementing the commitment by the LFR country. Secondly, naming increases the transaction-specific nature of investments in reputation. Inclusion in a black list increases the value of the (sunk) investments in reputation. In terms of our analysis, for specific countries, the actual effect of the blacklisting procedures can be to increase the expected national benefits rather than improve international political enforcement. As we will point out later, other complementary countermeasures can be necessary to increase the expected costs of the non cooperative attitude.

Furthermore, a country that is engaged in money laundering and finds itself blacklisted will find it even more difficult to switch course and decide to exit the market, thus being encouraged to compete aggressively in the market. The final result does not change much. It still needs to move forward.

The second conclusion that can be reached based on the empirical evidence we have examined is that we must not exclude the possibility that there are LFR countries not presently ncluded in the FATF monitoring action. This is true, perhaps, because they are highly effective in bringing their formal rules in line with international precepts, while in their deeds they remain lax in the fight against black money. By the same token, by modifying their formal rules former NCCT countries could not automatically cease to be lax countries, since the incentives for laxity in combating the laundering of illicit capital may be very deep-rooted (false friend effect).

This is not to say that the international community should not endeavor to list countries involved in the market for money laundering services. What this paper argues, is that a "name and shame" approach per se, separated from other initiatives, could not produce effective results. Names should be named, but only if blacklisting goes hand in hand with other measures.

Appropriate countermeasures that increase the actual level of international political enforcement and/or the level of international reputation costs should be grounded on the premise that in a global world even the most efficient LFR country will still need to be integrated into the world financial markets.

This implies that no matter how many layers of transactions cover the predicate offence, terrorism or criminal organizations will still need to place that money within the lawful financial sector. This step is necessary, at a minimum, to exploit the capital in lawful uses, once it has been laundered. Money laundering is by definition instrumental to a later use. 
In this regard, there is one fundamental feature of the initiative taken by the FATF that appears to be pivotal for its success: the FATF has not limited its initiative to a mere recognition of "non co-operative countries and territories." FATF member states have also applied "Recommendation 21 " 29 to the countries included in the list. "Recommendation 21" requires a higher scrutiny by financial intermediaries in evaluating the suspect nature of transactions with counter parties, including legal persons, based in a country listed as non-cooperative. As a result of the FATF initiative, many countries included in the list have already taken initiatives aimed at overcoming the serious deficiencies observed by the FATF. ${ }^{30}$

These initiatives need to be evaluated in the medium-to-long term, because some of the enacted laws, for example, will require the issue of secondary regulations to become effective, or, more generally, the initiatives taken at the legislative level will need to be followed by concrete actions. It can be argued, however, that the threat of being crowded out by the international community has played a key role in spurring the adoption of the above mentioned initiatives. However it may be the case to go beyond that. The international community could to consider the possibility to introduce effective punitive measures, as a financial quarantine for every country that did not adhere to the international standards ${ }^{31}$. The G8 countries could play the role of promoting a complete strategy to combat black money focused on the financial quarantine threat; it could be the effective stick to intertwine with appropriate carrots in defining a new "name and shame" approach. Finally, the above conclusions imply a constant effort on the part of international organizations, particularly the FATF, to update the criteria and monitor the countries.

\footnotetext{
29 See FAFT, (1990). (2000). In addition, on June 2001the FAFT agreed to a process of stricter countermeasures for reluctant NCCTs; see Norgren (2004).

${ }^{30}$ See FAFT press communiqué of October $5^{\text {th }},(2000)$.

${ }^{31}$ On the possible features of a financial quarantine see Tanzi (2000).
} 


\section{Annex I}

\section{Money Laundering and Terrorism Finance, Formal and Informal Finance: Key Concepts}

Since 11 September 2001, the financial systems, overt and covert, have come increasingly into the sights of the state agencies appointed to combat terrorism. In that context, the need to increase the fight against the laundering of illicit capital was included in the agenda.

We should immediately stress that in terms of economic analysis the financing of terrorism (money dirtying) is a phenomenon conceptually different from the recycling of capital (money laundering).

To understand the similarities and differences, therefore, we must briefly review the economic peculiarities of the money-laundering phenomenon. In recent years, particular emphasis has been placed on the study of that phenomenon because of its central theoretical and practical role in the development of any crime that generates revenues.

In fact, the conduct of any illegal activity may be subject to a special category of transaction costs, linked to the fact that the use of the relative revenues increases the probability of discovery of the crime and therefore incrimination.

Those transaction costs can be minimised through an effective laundering action, a means of concealment that separates financial flows from their origin, an activity whose specific economic function is to transform potential wealth into effective purchasing power.

In this sense, money-laundering performs an illegal monetary function, responding to the demand for 'black finance' services expressed by individuals or groups that have committed income -producing crimes.

The financing of terrorism resembles money-laundering in some respects and differs from it in others. The objective of the activity is to channel funds of any origin to individuals or groups to enable acts of terrorism, and therefore crimes. Again in this case, a party with such an objective must contend with potential transaction costs, since the financial flows may increase the probability that the crime of terrorism will be discovered, thus leading to incrimination. Therefore, an effective money dirtying action, an activity of concealment designed to separate financial flows from their destination, can minimise the transaction costs. Thus, money dirtying can also perform an illegal monetary function, responding to the demand for 'covertness' expressed by individuals or groups proposing to commit crimes of terrorism.

The phenomena of nøney laundering and money dirtying may coexist, of course, when terrorism is financed through the use of funds originating from criminal activities. A typical example is the financing of terrorism with the proceeds from the production and marketing of narcotics. In those specific situations, at least on the logical level, the importance of the transaction costs is doubled, since the need to lower the probability of incrimination concerns both the 
crimes that generated the financial flows and the crimes for which they are intended. As a result, the value of a concealment operation is even more significant.

But who satisfies the demand for concealment, whether its purpose is moneylaundering or financing terrorism?

Drawing upon the literature on information asymmetries, it is easy to demonstrate that banking and financial intermediaries can perform an important function in the concealment activity, whether the underlying motive is moneylaundering or financing terrorism.

By reducing the overall transaction costs for the other economic agents, financial intermediaries improve the consumers' capacity to decide how to allocate their purchasing power in terms of consumption, savings and investment. Thus, intermediaries ultimately animate an industry in which the services offered and sold are intrinsically intangible, with an information content that is high but not uniformly distributed among all the market participants. The diverse characteristics of the operators are thus known to, and coordinated by, the financial firms through the supply and sale of their services, and the individual intermediaries seek to maximise their profit precisely through the management and enhancement of their information assets, in a sector where information is not uniformly distributed. Therefore, financial firms are ultimately characterised as having information assets greater than, different from and more specialised than, all the others. As a result, the financial industry acquires a reputation for two crucial attributes with regard to the purpose of concealment: a greater-than-normal degree of 'opacity' (information asymmetry), since the exchanges and flows of purchasing power are filtered, coordinated and administered by specialised operators; the privileged position of those intermediaries.

It should be stressed, however, that the connotation of incomplete, asymmetrical distribution of information between the parties stipulating the various forms of contract or agreement is accentuated in the provision of financial services but is not the exclusive prerogative of those markets. It manifests itself, for example, when the characteristics of the provision of professional services are examined. In any case, the quantitative and qualitative centrality of the financial industry within the overall economic system clearly evidences information asymmetry and centrality of the specialised operators.

Within the financial sector, a particular role is played by banks, intermediaries distinguished by the simultaneous offering of a) deposit contracts, fungible for payment and monetary requirements, and b) credit contracts, generally not transformable prima facie into market-negotiable assets. Banks thus emerge as a 'special' intermediary, since both their deposit and loan contracts provide them with significant economies of scale and diversification in the management of information. In markets 'opaque' by definition, they therefore become a depositary of confidential information on both the beneficiaries of loans and on the users of payment services, or whatever services they provide.

Management of the payments system also puts banks in a crucial position regarding the purpose of concealment. The more a payments system minimises the costs that operators pay to transform their potential options for allocating 
purchasing power into actual options, the more efficient it becomes. But, if this is true, that system can be a potentially optimal, efficient vehicle for transforming the potential purchasing power of illicit revenues into actual purchasing power and therefore for performing money laundering functions effectively. At the same time, through the payments system, the provision of funds to terrorist organisations can be concealed.

In other words, management of the payments system has a positive value for legal economic agents, since it facilitates their resource allocation decisions. At the same time, it may be crucial for illegal parties, which are seeking not only to reduce transaction costs but especially to minimise the risks of discovery - and therefore the costs of sanctions and punishment - associated with both moneylaundering and terrorism financing activities.

Banking and financial intermediaries are therefore at the centre of attention of both criminal and terrorist organisations and the law enforcement authorities. For criminal parties, the presence of intermediaries that are cooperative (contaminating intermediaries) or inefficient in protecting their integrity (unknowing intermediaries) increases the possibility of using the payments or lending systems, or financial services system in general, for their concealment objectives. At the same time, for the inquiring and investigative authorities, the information assets in the possession of those companies can serve an essential reporting function in the identification and verification of the presence of criminal or terrorist organisations or individuals.

To cast light on the similarities and differences between money laundering and money dirtying, we should dwell on the role of the unknowing intermediaries, to which the authorities assign the task of reporting suspicious financial movements.

Starting with money-laundering phenomena, we reconsider the definition of money laundering with respect to any financial transaction: that transaction not only performs an economic function of its own but, if its purpose is to launder funds, it also performs an additional irregular function.

The hypothesis is that precisely because the transaction in question is responding to an uncommon (and illegal) purpose, it will possess irregular features that distinguish it from normal, physiological characteristics. What will the sources of the irregularity be? The irregularity could arise from at least one of the baseelements of the definition of money laundering, in which an economic agent institutes procedures to transform a given amount of potential purchasing power into actual purchasing power. The irregularity could therefore refer to at least one of the three elements: the party, the procedures and the amount of a given banking or financial contract.

Thanks to past evolution, money-laundering techniques now pose greater difficulties of identification and monitoring, precisely because they have made concealment and the separation of the three components of a laundering operation increasingly effective. A first important point is therefore the growing difficulty of recognising money-laundering irregularities. A second important point is the fact that a banking or financial transaction may embody irregular elements without this signifying that it derives from a laundering attempt: irregularity can therefore be 
considered a necessary but insufficient condition for identifying money-laundering activity.

These reflections on the logical and operational difficulties related to the hypothesis of irregularity are strengthened when this postulate becomes the cornerstone on which the obligations of intermediaries to collaborate in the war on the financing of terrorism are based. It is wholly evident, in fact, that the existence or detectability of irregular elements can become even more problematic when the sources of the financial flows to be concealed are totally licit activities conducted by individuals or organisations equally overt and legal.

In summing up our analysis regarding the relationship between the laundering of capital and financing terrorism, one is prompted to think that the operational techniques, and therefore the channels of dissemination, of the two phenomena are at least in part coincident. It is important, however, for the partial coincidence of money dirtying and money laundering to remain a working hypothesis rather than a theorem, so that it is possible to attempt the construction of a system of rules that can combine the effective enforcement of laws with the efficiency of the banking and financial markets.

And it is precisely from the standpoint of possible channels for financing terrorism that the theme of informal finance emerges, although it is not a new concept.

The focus on the relationship between informal banking and financial systems, on the one hand, and the potential risks of money laundering and terrorism financing, on the other, is quite recent, and the few studies on the subject are exclusively descriptive in nature.

From the standpoint of economic analysis, the description of those systems leads us to conclude that those informal networks, beyond the obvious historical, geographical and technical-operational differences, seem to be distinguished by the following: informality and trust on an ethical basis.

Informal finance systems, in fact, develop without the stable or long-lasting support of a system of formal laws, administrative rules, and relative documentary, paper-based records, as is characteristic of formal finance systems, bank-based and otherwise. The fuel and catalyst of these systems is ethics-based trust: in individual communities, strongly identified on the ethnic level, financial transactions are carried out that create de facto debtor-creditor relations of variable duration on the basis of a common fiduciary heritage. In informal systems, the reliability of these relations cannot be based, by definition, on the threat of legal sanctions but rests instead on the advisability of avoiding the social and moral sanctions that strike members of the reference community who fail to fulfil their obligations, with highly concrete effects associated with exclusion and isolation.

The systems of informal finance thus seem to be heavily used by migrants belonging to the ethnic communities from which these systems originated. This observation is obviously not based on robust statistical series, given the covert nature of the phenomenon, but on a growing volume of specific case studies and on specific sample surveys. 
The combination of high fiduciary content and ethnic affinity makes those informal, naïve channels - consisting of networks among friends and relatives of the same ethnic group as the immigrant or by more complex structures of informal finance - particularly attractive. The use of ethnic-national networks is strictly tied to the strength of relationships of trust among immigrant compatriots.

Informal finance is characterised by great simplicity and rapidity of procedures, operational flexibility, and a capacity to adjust to the needs of the migrants. Informal finance also displays maximum capacity in integrating the economic element into the social context and in linking organisational decisions to cultural influences and traditions. The operations of informal financial institutions are based on trust and on gradually established schemes and procedures and customary rules. The functioning of informal finance mechanisms is normally ensured by 'social control', i.e. the censure of improper conduct exercised by the community through the marginalisation of migrants who fail to adhere to the rules (typically ethical or religious rules linked to the cultural background). It is not rash to maintain, in fact, that the mechanism for enforcing the relations created within informal networks is repeated within the local immigrant communities, which are particularly sensitive to cultural identity and relative 'marginalisation risk'.

The assurance of confidentiality and the minimal request of information are known to be crucial aspects of the banking and financial industry, and become even more so where some specific customer characteristics are present: illegal immigrants; legal immigrants but with little clarity/legality regarding their socialsecurity, employment and residential positions; legal immigrants with a preference for informal channels for regulatory reasons (fiscal aspects, rules on currency flows, etc) in the country of origin; legal immigrants who, for psychological motives, dictated by the social context of the host country, desire minimal visibility and do not appreciate any type of control or disclosure of personal information.

In the relationship between informal finance and migrants, in essence, we find yet another example of the now-classic lesson of recent economic analysis: exchanges occur only where there is information and sufficient trust. In effect, the capacity of the informal systems to succeed where the formal systems tend to fail has been explored by economic analysis, particularly regarding credit mechanisms.

Under certain conditions, therefore, the informal systems are more efficient than the formal systems. Unexplored, on the other hand, is the relationship between covertness and integrity, in terms of the risk that these channels may satisfy the demand for illegal financial services, and particularly serve for purposes of moneylaundering and financing terrorism.

Based on the considerations advanced earlier regarding the characteristics that make a system attractive to those individuals or organisations wishing to conceal the origin or destination of given monetary flows, it seems evident that informal finance may appear particularly effective with respect to these purposes.

Both money laundering and money dirtying are based on a need for concealment. Informality, other conditions being equal, reduces the traceability of both the origin and destination of the financial flows. While the sharing of common fiduciary assets also imposes confidentiality, or better secrecy, the impermeability of informal systems to the acquisition of information by outsiders is greatly 
reduced, especially if the outsiders are authorities, and all the more if they are representatives of foreign countries. Therefore, at least at the level of deductive reasoning, the riskiness of informal finance systems, in terms of their use by criminal or terrorist organisations, seems greater than that attributable to overt finance, banking and non-banking.

\section{Annex II}

\section{Lax Financial Regulation: Key Concepts}

The relationship between money laundering and national fin ancial regulation is key issue in the international debate. To discuss this issue from an economic point of view it can be useful to treat the regulation of money laundering as a product, with a demand and supply schedule. But whose demand schedule is driv ing the system?

We assume that the policymaker in a given country has not yet decided the direction that it will impose on its financial regulation, with specific regard to money laundering. The policymaker may thus decide to implement regulations that create serious obstacles to money laundering, and thus to terrorism and organised crime, or it may decide - at the other extreme - to make the opposite choice, devising lax regulations that facilitate money laundering.

Money laundering generates costs as well as benefits for the parties involved. The costs for society depend on the fact that more predicate offences will be committed by terrorist or criminal organisation if money laundering is possible, and on the possible negative impact that money laundering will have on the economic system.

The benefits of money laundering accrue, first of all, to terrorist and criminal organisations, which can employ the proceeds of crime and avoid the threat of prosecution for predicate offences (money laundering in the strict sense), or which can use legal capital to finance illegal activities (money dirtying). The similarities and differences between money laundering and money dirtying were discussed above and in Annex I.

On the other side of the transaction, money laundering offers the host country the possibility to earn a 'commission' in exchange for its services - what we can call the expected national benefits due to lax financial regulation.

Therefore, we can identify four different categories of actors potentially interested in regulation: a) the policymakers; b) terrorist and criminal organisations, deriving utility from the possibility of laundering money; c) those who bear the costs of money laundering; d) the financial community and, in general, the citizens that receive benefits from the inflow of foreign black and grey capital.

Starting with this last category, it seems difficult to predict which side the financial community will take. In general, we tend to think that the utility function of financial intermediaries does not appear to be affected by whether profits stem from legal or illegal financial activities (pecunia non olet). We think that they simply maximise the expected revenues, and that, given the asymmetric 
information issues, they are not able to distinguish clearly the customers' nature, legal or illegal.

The interests of b) and c) are obviously incompatible, as the gains of the former depend on the losses of the latter; a) appears to be caught in the middle, having to decide which demand schedule to follow.

Note that we are not assuming that b) and c) are necessarily based outside the country where the policymaker we are concerned with is based. This is not an assumption, but rather the consequence of our line of argument. As with all policy issues, as long as the costs and benefits of a decision fall within the boundaries of the area of influence of the policymaker, we expect to have an efficient decision. Policymakers in countries where crime or terrorism is pervasive will tend to bear at least some of the costs associated with a decision to favour money laundering.

Countries where organised crime or terrorism is pervasive might appear to play a minor role in the offer of black or grey financial services at the international level, because they are sensitive to terrorism - and crime - related national costs. This might be so because the widespread presence of organised crime or terrorism in the country increases, for the policymaker, the costs of regulations that favour money laundering.

The public will bear the costs of the decision and will hold the policymaker responsible. Entering the international market for money laundering services has a greater potential for countries that are immune from terrorist or criminal activities. By definition, such countries will almost be able to externalise the costs associated with the increase of predicate offences. A negative correlation between crime rate or terrorist episodes in the country and the role played in the offering of money laundering services appears likely.

As a result of this process, some countries which do not bear the costs associated with money laundering become predisposed to adopting lax regulations that facilitate money laundering. The other side of the coin is that both criminal and terrorist organisations and those who bear the costs stemming from money laundering will 'naturally' tend to be situated in countries other than the one where the regulations are adopted.

We have thus limited our attention to policymakers that are based in countries different from those which the other actors potentially interested in the regulations are based in. From this starting point, the confrontation between those who benefit from money laundering and those who suffer from it is almost a 'win-win' game for criminal and terrorist organisations.

Organised crime and terrorism enjoy huge asymmetrical organisational advantages over those who bear the costs of money laundering. A small, powerful group opposes a large, dispersed group, thus making the outcome predictable.

To be sure, money-laundering regulation could be opposed, and indeed is opposed, by political authorities that represent the public interest. The dispersion of the costs, however, makes money laundering a low salience issue for the public, and consequently quite low on the political agenda. The man on the street simply does not feel the bite of money laundering, and political actors will act as a consequence. 


\section{References}

Alexander, K. (2001), The International Anti-Money Laundering Regime: The Role of the Financial Action Task Force, Journal of Money Laundering Control, vol.4, n.3, pp.231-248.

Alldridge, P. (2001), Are Tax Evasion Offences Predicate Offences for Money Laundering Offenses, Journal of Money Laundering Control, vol.4, n.4, pp.350-359.

Alwort, J. and Masciandaro, D. (2004), Public Policy: Offshore Centre and Tax Competition: The Harmful Problem, in D. Masciandaro (ed.), Global Financial Crime. Terrorism, Money Laundering and Offshore Centres, Ashgate, Aldershot, (forth.).

Banoun R., Cephas, D. and Fruchtman, L.D. (2002), US Patriot Act and Other Recent Money Laundering Developments Have Broad Impact on Financial Institutions, Journal of Taxation of Financial Institutions, v.15, n.4.

Basel Committee on Banking Supervision (1988), Prevention of Criminal Use of the Banking System for the Purpose of Money-Laundering, Basel.

Becker, G.. (1968), Crime and Punishment: an Economic Approach, Journal of Political Economy, n.2, pp. 169-217.

Boeschoten, W. and Fase, M. (1992), The Demand for Large Bank Notes, Journal of Money, Credit and Banking, vol. 2, n. 3.

Davis, K. (2003), Legislating against the Financing of Terrorism: Pitfalls and Prospects, Journal of Financial Crime, vol. 10, n.3, pp.269- 274.

Drazen, A. (2000), Political Economy in Macroeconomics, Princeton, Princeton University .

Errico, L. and Musalem, A. (1999), Offshore Banking: An Analysis of Micro- and Macro-Prudential Issues, Working Paper of the International Monetary Fund, n. 5.

Financial Action Task Force (2000), Review of Non-Co-operative Countries or Territories: Increasing the Worldwide Effectiveness of Anti-Money Laundering Measures.

Financial Action Task Force (1990), The Forty Recommendations.

Hampton, M.P. and Christensen J. (2002), Offshore Pariahs? Small Island Economies, Tax Havens, and the Re-configuration of Global Finance, World Development, vol.30, n.9, pp.1657-1673.

Holder, W.E (2003), The International Monetary Fund's Involvement in Combating Money Laundering and the Financing of Terrorism, Journal of Money Laundering Control, vol.6, n.4, pp.383-387.

International Monetary Fund (1998), Money Laundering. The Importance of International Countermeasures, address by Michel Camdessus, Plenary Meeting of the FATF, pp. 1-4, mimeo.

Jayasuriya D., (2003), Money Laundering and Terrorism Financing: The Role of Capital Market Regulators, Journal of Financial Crime, vol. 10, n.1, pp.30-36. 
Johnson, J. (2001a), In Pursuit of Dirty Money: Identifying Weaknesses in the Global Financial System, Journal of Money Laundering Control, vol.6, n.1, pp.122-132.

Johnson, J. (2001b), Blacklisting: Initial Reactions, Responses and Repercussions, Journal of Money Laundering Control, vol.6, n.3, pp.211-225.

Johnson, J. and Lim, Y.C.D. (2002), Money Laundering: Has the Financial Action Task Force Made a Difference?, Journal of Financial Crime, vol.10, n.1, pp.722.

Masciandaro D. (2004) (ed.), Global Financial Crime. Terrorism, Money Laundering and Offshore Centres, Ashgate, Aldershot, (forth.).

Masciandaro, D. (2000), The Illegal Sector, Money Laundering and Legal Economy: A Macroeconomic Analysis, Journal of Financial Crime, n.2, 103112.

Masciandaro, D. (1999), Money Laundering: the Economics of Regulation, European Journal of Law and Economics, n.3, May, pp 245 - 240.

Masciandaro, D. (1998), Money Laundering Regulation: the Micro Economics, Journal of Money Laundering Control, Vol.2, n.1, pp. 49 - 58.

Masciandaro, D. (1996), Pecunia Olet? Microeconomics of Banking and Financial Laundering, International Review of Economics and Business, October, pp817844.

Masciandaro, D. and Portolano, A. (2003), It Takes Two to Tango: International Financial Regulation and Off-shore Centres, Journal of Money Laundering Control, vol.6, n.4, pp.311-331.

Masciandaro, D. and Portolano, A. (2004), Financial Policies: Offshore Centres and Competition in Regulation: The Laxity Problem, in D. Masciandaro (ed.), Global Financial Crime. Terrorism, Money Laundering and Offshore Centres, Ashgate, Aldershot, (forth.).

Mitchell, D.J. (2003), US Government Agencies confirm that Low Tax Jurisdictions are not Money Laundering Havens, Journal of Financial Crime, vol. 11, n.2, pp.127-133.

Norgren, C. (2004), The Control of Risk Associated with Crime, Terror and Subversion, Journal of Money Laundering Control, vol.7, n.3, pp.201-206.

Persson, T. and Tabellini, G. (2000), Political Economics: Explaining Economic Policy, Cambridge M.A., MIT University Press.

Preston, E. (2003), The US Patriot Act: New Adventures in American Extraterritoriality, Journal of Financial Crime, vol. 10, n.1, pp.104-116.

Rider, B.A.K. (2003), Financial Regulation and Supervision after $11^{\text {th }}$ September, 2001, Journal of Financial Crime, vol. 10, n.4, pp.336-358.

Rider, B.A.K. (2002), Weapons of War: the Use of Anti - Money Laundering Laws against Terrorist and Criminal Enterprises, International Journal of Banking Regulation, vol.4, n.1, pp.13-31.

Rogoff, K. (1997), Foreign and Underground Demand for Euro Notes: Blessing or a Curse?, Working Paper, 1997.

Romano, R. (1999), Corporate Law and Corporate Governance, 365, in Firms, Markets, and Hierarchies, G .R. Carroll and D. J. Teece eds, New York.

Romano, R. (1993), The Genius of American Corporate Law, Washington, D.C. 
Romano, R. (1985), Law as a Product: Some Pieces of the Incorporation Puzzle, in 1 Journal of Law, Economics, and Organisation, 225.

Sinn, H.W. and Westermann, F. (2001), Why has the Euro been falling?, CESIfo Working Paper No. 493, May.

Tanzi, V. (200), Money Laundering and the International Financial System, in Policies, Institutions and the Dark Side of Economics, Edward Elgar, Cheltenham, pp. 186-200.

Van Cleef, C. (2003), US Patriot Act: Statutory Analysis and Regulatory Implementation, Journal of Financial Crime, vol. 11, n.1, pp.73-101.

Von Furstenberg, Terrorist Finance: Within the Grip of the G8, this volume.

Wasserman, M. (2002), Dirty money, Regional Review, Federal Reserve Bank of Boston, v.12, n.1, pp14-21.

Yaniv, G. (1994), Taxation and Dirty money laundering, Public Finances/Public Finance, 49 (Supplement), pp. 40-51

Yaniv, G. (1999), Tax Evasion, Risky Laundering, and Optimal Deterrence Policy, International Tax and Public Finance, 6, pp. 27-38. 